\title{
EVALUATION OF ECOSYSTEM SERVICES LOSS DUE TO URBAN SPRAWL ON AGRICULTURAL LAND IN THE CONTEXT OF SUSTAINABLE DEVELOPMENT
}

\author{
KATERINA VRUBLOVA \\ Palacky University Olomouc, Faculty of Science, 17. listopadu 1192, 77900 Olomouc, \\ Czech Republic \\ *Corresponding author e-mail: katerina.vrublova@gmail.com
}

Received: $15^{\text {th }}$ October 2020, Accepted: $8^{\text {th }}$ November 2020

\begin{abstract}
This paper focuses on the ecosystem services which are provided by agriculture land and on the urban sprawl in the study area of municipality with extended powers Třebíč. The main focus of this article is to evaluate what ecosystem services are provided to Czech society by the agricultural land and assess their financial value and also evaluate which ecosystem services disappear or are limited due to urban sprawl on agricultural land. Generally, the topic of ecosystem services in agriculture comes under focus especially in view of the recurring drought in Europe and on-going climate change. Also the subject of urbanization and decreasing area available for agriculture is a wide-spread phenomena in Europe. The practical output of this paper will comprise of better insight on function and value of land under agriculture use which is lost due to urban development and raising the awareness amongst the society on the fast-growing trend of unsustainable urban sprawl.
\end{abstract}

Keywords: Agriculture, ecosystem services, farming practices, soil erosion, nutrient runoff, carbon sequestration, urban sprawl

\section{INTRODUCTION}

Ecosystem services and their evaluation is a concept which has been long gaining steam amongst scientists. The idea behind this concept is to assess the value of those services that nature provides to us (e.g. provision of oxygen through photosynthesis, climate regulation, carbon sequestration, food production, recreation etc.). It also became self-evident that we do need to put forward this concept and raise the awareness just as the value of these ecosystems is declining and we face a severe biodiversity loss in span of just a couple of decades. Through the ecosystem services evaluation we help to transform these values into a concept that every citizen would understand - into monetary value. This aims to bring the attention to severe ecosystem services loss and bring this closer to everyday discourse, outside of the scope of purely scientific bodies.

The notion of naming and systematizing services provided by nature and environment to the human population began to take shape in the 1970's with the term "environmental services", which has been introduced in the 1970 report of the Study of Critical Environmental Problems (SCEP, 1970). 
Later the term "ecosystem services" was coined and it has been used in the scientific circles ever since. The term itself was first used by Ehrlich \& Ehrlich (1981). Then the ecosystem services came into wider knowledge in the 1997 following among other things the publication of the article "The value of the world's ecosystem services and natural capital" (Costanza, 1997) and the book Nature's services: Societal dependence on natural ecosystems (Daily, 1997). Costanza defines ecosystem services as: "benefits human populations derive, directly or indirectly, from ecosystem functions" (Costanza, 1997) while Daily describes them as: "conditions and processes through which natural ecosystems, and the species that make them up, sustain and fulfil human life" (Daily, 1997). These definitions were later expanded in the Millennium Ecosystem Assessment into: "benefits people obtain from ecosystems. These include provisioning services such as food and water; regulating services such as regulation of floods, drought, land degradation, and disease; supporting services such as soil formation and nutrient cycling; and cultural services such as recreational, spiritual, religious and other non-material benefits." (MEA, 2005) Yet this concept is under scrutiny and several lead authors have acknowledged the need to keep this as an evolving concept (see Carpenter et al., 2006; Sachs \& Reid, 2006).

When speaking about the concept of ecosystem services, there needs to be a clear distinction in terminology. In research, the term ecosystem comes together usually with the terms structure, function and finally the service. However, this does not mean that they are identical or synonymous. Ecosystem structure and function have been identified and studied for years without making any reference to the services to humans, which they also provide. Even as most ecosystem structures and processes do provide services they are not the same thing. Indeed, as mentioned above, the ecosystem services are only relevant when speaking about the benefits they provide to humans; otherwise the concept would not exist (Fisher, 2009).

The measurement, modelling and monitoring of ecosystem functions are the foundation for ecosystem service valuation and are thus the basis for the sustainable use of biodiversity, ecosystems and natural resources in general (Carpenter et al., 2009). These different methods are discussed in detail through a variety of reviews and guidelines - for example, Barbier (2007), Bateman (2007), Bateman et al. (2002a), Champ et al. (2003), Freeman (2003), Hanley \& Barbier (2009), Heal et al. (2005), Kanninen (2006) and Pagiola et al. (2004). The evaluation of ecosystem services in economic terms became an increasingly popular approach not only to assess alternative land use strategies but also to demonstrate and justify the need for the conservation of biodiversity (Bayon \& Jenkins, 2010; Chan et al., 2007; Costanza et al., 1997; de Groot et al., 2002; Fisher et al., 2009; Ghazoul, 2007a, 2007b; Ridder, 2008; Wallace, 2007).

\section{METHODOLOGY}

The objective of this research is to determine the value of ecosystem services provided by agriculture land which is lost due to urban sprawl. As many hectares of agriculture land a year are lost due to urban development, this valuation would serve as an argument for preserving agriculture land and preventing urban sprawl. The study area dedicated for this research is the municipality with extended powers Třebíč. This research aims to collect the data on the amount of agriculture land lost to urbanization in Třebíc and evaluate the ecosystem services that could no longer be provided by this land.

This topic was chosen in the light of the ever-growing rate of urban sprawl in Czech lands without sufficient policy and argumentation tool to address this trend. Hopefully the notion of ecosystem services evaluation might help to scale back this negative development. 
Vrublova K.: Evaluation of ecosystem services loss due to urban sprawl on agricultural land in the context of sustainable development

The default hypothesis which is basis for this research is as follows: "The value of ecosystem services provided by agriculture land in the municipality with extended powers Třebič has decreased due to urban sprawl."

From this hypothesis stems the main research question:

What is the value of ecosystem services provided by agriculture land which has been lost due to urban sprawl in the region of Třebič?

This main research question will be divided into three more specific research question:

- Research question 1: What are the different ecosystem services provided by agriculture land?

- Research question 2: What is the value of these ecosystem services?

- Research question 3: What amount of agriculture land has been lost due to urban sprawl?

To allow comparability between the results for different ecosystem services, the research focused on the main land use types in agriculture in the Czech Republic and the following crops: wheat, barley, rapeseed, maize and grassland.

To determine answer to research question one desk research was used to conclude which ecosystem services are provided by agriculture land and more importantly for which of these ecosystem services can we determine their value. The preliminary research has identified these ecosystem services which can be remunerated in terms of this study: nutrient run-off, carbon sequestration, prevention of erosion, production function.

To determine the nutrient runoff and carbon sequestration (both methodologies shall be described together, as the collection of data for both of them was done simultaneously) on agriculture land and evaluate the belonging ecosystem services involved several steps. The first step was to collect data on different samples of agriculture land with different type of management through case studies. Case studies were chosen in the municipality with extended powers Třebíc and to provide multiple samples, farms with different type of management were chosen, ranging from small ecological farms with prevalent permanent grassland to big farms with cereal production and animal production. As this research was conducted as part of the study commissioned by the Ministry of Agriculture on the provision of public goods and ecosystem services through agro-envi-climate measures, all farms had part of their land designated as grassland on arable land under this scheme. Farms were chosen through the database provided by the Ministry and to provide anonymity for the responders, no names were included in the published outcomes. To collect the data, qualitative semi-structured questionnaire (mixing closed and open question) was prepared to get all the needed data to feed into the models used for this exercise. The nutrient run-off was investigated through modelling, which required following inputs: field water capacity, harvest index, depth of roots, average yield, nitrogen need of individual plants, mineralized nitrogen and effective rainfall. The data input for the Cool Farm Tool, the model destined to determine the carbon sequestration, was structured in a slightly different manner: Yields per hectare, soil characteristics, amount of organic matter in soil, the percentage amount of land with no tillage during the year, cover crop, fuel consumption for transport and field operations, electric energy consumption, fuel consumption for transport outside of the farm, the amount of straw left on the field.

To determine the cost for nutrient run-off, the total amount of nutrients fed into the waterways was compared with the price it takes to clean the water from these nutrients in a water treatment plant. 
For the costs related to carbon sequestration, the so-called Social Cost of Carbon (SSC) might be used for assessing the value of carbon sequestration in ecosystems, since those very ecosystems contribute to climate change mitigation. Social cost of carbon is the cost of each tonne of carbon dioxide which is being emitted as a consequence of climate change. This social cost is evaluated according to the integrated models for economics of climate change.

When determining the ecosystem service (or in this case the obvious disservice) for prevention of soil erosion, one has to consider all the aspects related to this service. The assessment of yearly soil loss due to soil erosion was done with the help of ArcGIS software. The soil erosion shall be calculated per crop type to evaluate the differences in crop management. The average annual loss of soil due to erosion was calculated for those blocks with selected crops based on the data received from LPIS. The data was requested from the paying agency under the Czech Ministry of Agriculture. As for costs for preventing soil erosion, average soil loss determines the amount of fertile land which is lost. The next thing that happens is that this soil contaminates the water and is being swept away in the river flow. By default, the nutrients which are embedded in the soil are lost. Therefore, we first need to determine the price of these nutrients. Next is the price of the soil itself. As the soil which has been run off from the field contaminates the water and builds up in the nearest water body, the costs for clearing up the water body have to be considered together with the costs for transporting the soil and storing it in a landfill.

The production function of agricultural land was determined through a simple method of direct market value.

The answer to research question three, the number of hectares of agriculture land lost due to urban sprawl were determined via a collection of data from the Czech Statistical Office and from the State Administration of Land Surveying and Cadastre.

\section{CASE STUdies}

The overview of the selected farm types:

- Farm 1 - Mixed medium sized privately-owned ecological farm (81 pieces of cattle, 23 horses, 6 sheep), grassland on arable land, permanent grassland and pastures, 130.47 ha in total

- $\quad$ Farm 2 - Large conventional farm (wheat, maize, rapeseed, alfalfa, low percentage of grassland), 579.98 ha in total

- Farm 3 - Large conventional mixed farm (wheat, maize, rapeseed, permanent grassland, 1000 pieces of cattle, biofuel station), 1172.56 ha in total

- Farm 4 - Large conventional mixed farm (wheat, rapeseed, maize, barley, permanent grassland, 30000 chicken, 420 dairy cows), 3487.45 ha in total

- Farm 5 - Small privately-owned ecological farm with cattle, horses, sheep and pigs, 25.41 ha in total

- $\quad$ Farm 6 - Small privately-owned mixed farm (wheat, barley, permanent grassland, 35 pieces of cattle), 94.30 ha in total

\section{RESULTS}

\section{Nutrient run-off}

The outcome from the nutrient flow model showed values for three basic nutrients in agriculture, nitrogen, potassium and phosphorus while the results from the nitrogen balance 
Vrublova K.: Evaluation of ecosystem services loss due to urban sprawl on agricultural land in the context of sustainable development

in soil pointed out to excess nitrogen residue in some cases. The model for nitrogen leaching established what amount of nitrogen is leached per hectare per designated crop.

Acquired data were used to evaluate what rate of nitrogen is being leached from arable land in the Czech Republic as shown in Table 1 and what is an average value for nitrogen leaching in arable land.

Table 1: Nitrogen leaching in the Czech Republic

\begin{tabular}{|l|l|l|l|}
\hline Crop & 2016 crop area (ha) & Nitrogen leaching kg N/ha & Nitrogen leached (t) \\
\hline Wheat & 839710,5 & 48,1 & 40390,07 \\
\hline Barley & 325725,3 & 40,6 & 13224,45 \\
\hline Rapeseed & 392991,3 & 47,4 & 18627,79 \\
\hline Maize & 241500,0 & 29,2 & 7051,80 \\
\hline Grassland 2017 & 9832,93 & 30,7 & 301,87 \\
\hline Grassland for fodder & 114093,58 & 29,1 & 3320,12 \\
\hline Sum & $\mathbf{1 9 2 3 ~ 8 5 3 , 5 6}$ & & $\mathbf{8 2 9 1 6 , 1 0}$ \\
\hline
\end{tabular}

Source: original

The expenditure on cleaning the leached nitrogen from water was determined according to data obtained from water treatment plant. Detailed data on water treatment methods were acquired from plants of different capacity shown in Table 2 (small, medium and large capacity) from which the rate of water treatment expenditure on nitrogen and phosphorus cleaning was separated. It has to be noted that since these two nutrients are cleaned together in the technological process, the price for their cleaning cannot be separated.

Table 2: Expenditure on nitrogen and phosphorus cleaning per water treatment plant

\begin{tabular}{|l|l|l|l|}
\hline & $\begin{array}{l}\text { Expenditure for } \\
\text { water cleaning } \\
\text { in 2017 (CZK) }\end{array}$ & $\begin{array}{l}\text { Expenditure } \\
\text { for cleaning } \\
\text { nitrogen } \\
\text { (CZK) }\end{array}$ & $\begin{array}{l}\text { Expenditure for } \\
\text { cleaning } \\
\text { potassium }(\mathbf{C Z K})\end{array}$ \\
\hline 1 - Large water treatment plant & 336,3 & 302,4 & 33,9 \\
\hline 2- Medium water treatment plant & 340,6 & 306,3 & 34,3 \\
\hline 3- Small water treatment plant & 366,6 & 329,7 & 36,9 \\
\hline Average & & 312,8 & 35,0 \\
\hline Total & & & $\mathbf{3 4 7 , 8}$ \\
\hline
\end{tabular}

Source: calculation according to water treatment plant data and price of water delivery

When combining these two aspects - the amount of nitrogen leeched per hectare and the price for cleaning the nitrogen, the final ecosystem service can be easily determined (see Table 3). 
Table 3: Nitrogen leaching per crop

Source: original

\begin{tabular}{|c|c|c|}
\hline Crop & $\begin{array}{l}\text { Nitrogen } \\
\text { leaching } \\
\text { kg N/ha }\end{array}$ & $\begin{array}{l}\text { The cost of } \\
\text { nitrogen leached } \\
(\mathrm{CZK} / \mathrm{ha})\end{array}$ \\
\hline Wheat & 48,1 & 16729,18 \\
\hline Barley & 40,6 & 14120,68 \\
\hline Rapeseed & 47,4 & 16485,72 \\
\hline Maize & 29,2 & 10155,76 \\
\hline Fodder & 29,1 & 10120,98 \\
\hline
\end{tabular}

As the table shows, when it comes to nutrient run off and especially nitrogen leaching, the agriculture land with the main types of crops provide a disservice. This means that instead of providing the service of prevention of water contamination, they enable it.

\section{Carbon sequestration}

The factors that play a role when determining how much carbon is sequestrated at a farm is the amount of fuel used or transportation mode - basically the farm management. This is closely linked to crop which is being grown at the farm. With the use of the model, the carbon sequestration per crop was determined and it was linked with the average value for social cost of carbon to establish how much does the crop contribute to the ecosystem service of carbon sequestration (see Table 4).

For the Social Cost of Carbon, the average value of carbon is based on $3 \%$ bank rate while estimating a yearly damage as a consequence of climate change until year 2050. The lower estimate for the social cost is based on $5 \%$ bank rate and the high estimate on $2.5 \%$ bank rate for aggregated impacted based on the current value. The results for these estimates are:

- Low estimate $-867 \mathrm{CZK}$

- $\quad$ Average estimate $-2836 \mathrm{CZK}$

- High estimate -8272 CZK.

For the purposes of this article, the average estimate was used.

Table 4: Carbon sequestration per crop for the case studies in the study area

\begin{tabular}{|l|l|l|}
\hline Crop & $\mathbf{C O}_{\mathbf{2}} \mathbf{t} / \mathbf{h a}$ & $\begin{array}{l}\text { The social cost of carbon } \\
\text { sequestrated (CZK/ha) }\end{array}$ \\
\hline Wheat & 0,82 & 2325,52 \\
\hline Barley & 0,62 & 1758,32 \\
\hline Rapeseed & 2,17 & 6154,12 \\
\hline Maize & 0,74 & 2098,64 \\
\hline Grassland for fodder & $-0,21$ & $-595,56$ \\
\hline
\end{tabular}

Source: original 
Vrublova K.: Evaluation of ecosystem services loss due to urban sprawl on agricultural land in the context of sustainable development

\section{Soil erosion}

The average value of soil erosion per crop type shown in Table 5 was calculated based on the data provided from the Czech paying agency through a GIS modelling.

Table 5: Average soil erosion per crop type in the study area

\begin{tabular}{|l|l|l|l|l|l|}
\hline & $\mathbf{2 0 1 5}$ & $\mathbf{2 0 1 6}$ & $\mathbf{2 0 1 7}$ & $\mathbf{2 0 1 8}$ & Average \\
\hline Wheat & 4,36 & 4,71 & 4,35 & 3,92 & 4,33 \\
\hline Barley & 4,35 & 4,3 & 4,45 & 4,19 & 4,32 \\
\hline Rapeseed & 3,32 & 4,51 & 4,88 & 3,07 & 3,94 \\
\hline Maize & 3,94 & 4,03 & 4,09 & 4,18 & 4,06 \\
\hline Fodder mix & 5,06 & 4,92 & 4,73 & 4,83 & 4,88 \\
\hline
\end{tabular}

Source: own calculation

With the costs linked to soil erosion and loss of soil it was easy to make the calculation of the ecosystem disservice provided by different type of crops on arable land due to soil erosion, as seen in Table 6.

Table 6: The costs linked to average soil erosion per crop type in the study area

\begin{tabular}{|l|l|l|}
\hline & Average soil erosion (t/ha/year) & Costs linked to soil erosion $(\mathbf{C Z K} / \mathbf{h a})$ \\
\hline Wheat & 4,33 & 29584,292 \\
\hline Barley & 4,32 & 29515,968 \\
\hline Rapeseed & 3,94 & 26919,656 \\
\hline Maize & 4,06 & 27739,544 \\
\hline Fodder mix & 4,88 & 33342,112 \\
\hline
\end{tabular}

Source: own calculation

\section{Production function}

To determine the production function of each of the selected crops, the total average yield was first determined as according to the agriculture norms. The average market price for each crop was also determined, for these the data from Czech Statistical Office on agriculture production was used and average was calculated. To introduce a weighting factor, a total cropland in the Czech Republic was determined and the total share of the selected crops in this cropland.

Finally, these data were combined to determine the production function per crop and the average production function in the Czech Republic, shown in Table 7. 
Table 7: Average production function in the Czech Republic

\begin{tabular}{|l|l|l|l|l|l|}
\hline Crop & $\begin{array}{l}\text { Average } \\
\text { yield }\end{array}$ & Average price & $\begin{array}{l}\text { Total } \\
\text { production }\end{array}$ & $\begin{array}{l}\text { Weighting } \\
\text { factor }\end{array}$ & $\begin{array}{l}\text { Final } \\
\text { value }\end{array}$ \\
\hline in t/ha & $\begin{array}{l}\text { in CZK per } \\
\text { tonne }\end{array}$ & CZK/ha & & CZK/ha \\
\hline Wheat & 6 & 4125,10 & 24750,60 & 0,42 & 10281,46 \\
\hline Barley & 5 & 4276,10 & 21380,50 & 0,16 & 3518,45 \\
\hline Rapeseed & 3,2 & 9275,60 & 29681,92 & 0,21 & 6194,40 \\
\hline Maize & 40 & 1000,00 & 40000,00 & 0,11 & 4537,27 \\
\hline Fodder & 5,2 & 1393,00 & 7243,60 & 0,10 & 709,22 \\
\hline & & & Average production in CZK/ha & $\mathbf{5 0 4 8 , 1 6}$ \\
\hline
\end{tabular}

Source: Agriculture norms, CSU 2019, own calculations

\section{Urban sprawl}

The reading of the data shows the overall trend in the area for the past 24 years. In total, the area dedicated to any of the land use type used in the cadastre registry has decreased by 3215 ha between years 1993 and 2017 - this is represented by a decrease of $3.7 \%$ in percentage value. The biggest decrease can be attributed to the share of agriculture land, which has decreased by 2589 ha or by $4.6 \%$. The largest share of agriculture land is arable land, which has therefore decreased accordingly by 1947 ha $(4.0 \%)$. Forest area and permanent grassland has also diminished quite significantly, with the former dropping by $3.4 \%$ (790 ha) and the latter by $10.1 \%$ (668ha). The area covered with gardens and orchards has decreased only very slightly, by 8 and 16 ha respectively. On the other hand, urbanized area has increased the most, by $6 \%$ (66 ha) while other area has increased by $1.2 \%$ (63 ha) and water surface has also developed by 28 ha. Overall, this underlines the trend seen not only here, but in the whole Czech Republic, that the areas with agriculture use are decreasing at the expense of urbanized and other areas.

\section{DISCUSSION}

The following table sums up the results for each ecosystem service identified for the purpose of this research.

This overview table clearly shows a trend that has been already been put forward in the literature review. Even as agriculture itself provides some services, most notably the production of food, it also draws up on the other services in its surrounding ecosystems and habitats. Some studies name this process, the clear loss of ecosystem services, as land degradation (Sklenička, 2016). Land degradation can be defined as: "reduction or loss of natural beneficial goods and services, notably primary production services, derived from terrestrial ecosystems" (Blaikie \& Brookfield, 1987; Sarukhan et al., 2005, Nkonya et al., 2011). This definition therefore embraces both human and natural causes to this process. The most common land degradation types are water and wind erosion, loss of biodiversity and in agricultural areas also water shortages, soil depletion and soil pollution (Nachtergaele et al., 2011) 
Vrublova K.: Evaluation of ecosystem services loss due to urban sprawl on agricultural land in the context of sustainable development

Table 8: Overview of the ecosystem services provided in the study area

\begin{tabular}{|l|l|l|l|l|}
\hline Crop & $\begin{array}{l}\text { Prevention of water } \\
\text { contamination - The } \\
\text { cost of nitrogen } \\
\text { leached (CZK/ha) }\end{array}$ & $\begin{array}{l}\text { Carbon } \\
\text { sequestration - The } \\
\text { social cost of } \\
\text { carbon } \\
\text { sequestrated } \\
\text { (CZK/ha) }\end{array}$ & $\begin{array}{l}\text { Production } \\
\text { function - Total } \\
\text { production } \\
\text { CZK/ha }\end{array}$ & $\begin{array}{l}\text { Prevention of soil } \\
\text { erosion - Costs } \\
\text { linked to soil erosion } \\
\text { (CZK/ha) }\end{array}$ \\
\hline Wheat & 16729,18 & 2325,52 & 24750,6 & 29584,292 \\
\hline Barley & 14120,68 & 1758,32 & 21380,5 & 29515,968 \\
\hline Rapeseed & 16485,72 & 6154,12 & 29681,92 & 26919,656 \\
\hline Maize & 10155,76 & 2098,64 & 40000 & 27739,544 \\
\hline $\begin{array}{l}\text { Grassland for } \\
\text { fodder }\end{array}$ & 10120,98 & $-595,56$ & 7243,6 & 33342,112 \\
\hline
\end{tabular}

Source: original

If we would consider the ecosystem service described in this work case by case, as for the prevention of water contamination (or nutrient run-off) it is clear that the arable land and the type of crops which are grown on this land benefit from a trade-off and provide a disservice to the environment. There are some differences between the crop types, with the grassland dedicated for fodder production clearly polluting the water bodies the least, yet the general trend does not change.

As for carbon sequestration, again the results clearly show that most of the crops grown on arable provide a disservice to the ecosystems in this regard, with the notable exception of grassland for fodder. The case studies also show very great differences between the farm types and farm management. The large conventional farm with mixed livestock and crop production managed to produce the staggering $19046871 \mathrm{CZK} /$ year in carbon footprint while the small family farm also with mixed production of livestock and crops managed to save $336297 \mathrm{CZK} /$ year.

As for the next ecosystem service considered in this research, the production of food is undeniably the one ecosystem service that all arable land does provide. It is also the one that cannot be replaced by any other ecosystem, certainly not in a manner that would sustain the current world population. There are some differences in what value does of the crop provide, with the least attributed to grassland for fodder and the most to maize production.

When it comes to soil erosion, it is clear again that the arable land with provides a disservice. There is no type of crop which would prevent the soil erosion altogether and there are also very small differences between the rate of erosion for the different crops.

One aspect which is also closely connected to soil erosion is the size of soil blocks. The analysis shows that the situation in the study area is not as dire as in the other parts of the Czech Republic as the average in the study area is slightly below the national average. The Czech Republic also has the largest average farm size in the EU (133 ha) and also in the study area this corresponds to the reality that more than $50 \%$ of the agriculture land is farmed by large cooperatives with more than 1000 ha of land. While this was not exactly in the scope of this paper, other studies have shown a link between an agriculture land fragmentation, land degradation and fragmentation of ownership.

This ownership fragmentation and therefore also tenure insecurity can also be one of the factors that lead to land degradation and the loss of ecosystem services. This land 
fragmentation, level of rented land and tenure insecurity boils down to the fact, which affects the land degradation the most. A number of studies have shown that farming on rented land is less sustainable while the tenant tends to care less for the land entrusted in them than the actual owners do. (Fraser, 2004; Carolan, 2005). The insufficient tenure security really strikes at the heart of land degradation, as it diminishes the motivation to invest in holdings, to increase the fertility of soil and it also decreases the motivation to invest in biodiversity protection, landscape renewal and water resource protection. (Sklenička, 2016)

As this research focuses on the ecosystem services loss due to urban sprawl, we have to analyse these facts together. As results show, the area dedicated to agriculture has decreased by $4.6 \%$ in the study area between years 1993 and 2017. During the same period, the urbanized area has increased by $6 \%$. There is no clear link saying that this agriculture land has been devoted to urban sprawl, yet the trend speaks clearly in the favour of urban development. When analysing the rate of agriculture land loss, $19 \%$ of the total area dedicated for urban development on agriculture land has already been transformed with some 1007 ha of land still unbuilt on.

Even as agriculture land does provide some disservices to the ecosystems and benefits from the surrounding habitats, it has a clear potential to improve on those disservices as outlined above. Yet if this cropland would be turned to urban land, there is no longer any of that potential. Even as it is possible to replace some of the ecosystem services lost, as outlined in the literature review, the most important function of agriculture land - food production - is hard to be replaced on a scale that would matter.

\section{CONCLUSION}

The main outcomes of this paper show that in most cases and for most of the typical arable crops in the Czech Republic, agriculture provides a disservice to the ecosystems rather than a service. The one notable exception is the provision of food, which is indeed the vital and primary function of agriculture land. There was evidence suggesting that permanent grassland could be much more benefitting in the terms of the provision of ecosystem services, yet it was not fully included in this study due to modelling limitations. The results also showed that much can be done for a better provision of ecosystem services through sustainable management of land and through implementation of different practices and measures. It should also be noted that the research focused solely on arable and did not study the benefits of features adhering to agriculture land, which often have much more value in terms of ecosystems and biodiversity

\section{ACKNOWLEDGMENTS}

I would like to thank my supervisor, Ivo Machar, who helped me a great deal with pulling off my doctoral thesis that was basis for this article. Similarly, I would like to thank my colleagues Tamara Faberova and Jaroslav Prazan who worked with me on the research cited in this article and also to the excellent GIS team in Ekotoxa ltd. for all their help. 
Vrublova K.: Evaluation of ecosystem services loss due to urban sprawl on agricultural land in the context of sustainable development

\section{REFERENCES}

Barbier, E.B. (2007). Valuing ecosystem services as productive inputs. Econ Policy 22:177229

Bateman, I.J. (2007). Valuing preferences regarding environmental change. In: Pretty, J., Ball, A., Benton, T., Guivant, J., Lee, D., Orr, D., Pfeffer, M., Ward, H. (eds.). The SAGE handbook of environment and society (pp 155-171). Sage, London.

Bayon, R., Jenkins, M., (2010). The business of biodiversity. Nature 466, 184-185.

Blaikie, P., Brookfield, H., (1987). Land Degradation and Society. Methuen, London.

Carolan, M.S., (2005). Barriers to the adoption of sustainable agriculture on rented land: an examination of contesting social fields. Rural Sociol. 70, 387-413.

Carpenter, S.R., DeFries, R., et al., (2006). Millennium ecosystem assessment: research needs. Science 314 (5797), 257-258.

Carpenter, S.R., Mooney, H.A., Agard, J., Capistrano, D., Defries, R.S., D1'az, S.,Dietz, T., Duraiappah, A.K., Oteng-Yeboah, A., Pereira, H.M., Perrings, C., Reid, W.V., Sarukhan, J., Scholes, R.J. \& Whyte, A. (2009) Science for managing ecosystem services: beyond the Millennium Ecosystem Assessment. Proceedings of the National Academy of Sciences of the United States ofAmerica, 106, 1305-1312.

Champ, P.A., Boyle, K., Brown, T.C. (eds) (2003). A primer on non-market valuation, the economics of non-market goods and services, vol 3. Kluwer Academic Press, Dordrecht.

Chan, K.M.A., Pringle, R.M., Ranganathan, J., Boggs, C.L., Chan, Y.L., Ehrlich, P.R., Haff, P.K., Heller, N.E., Al-Krafaji, K., Macmynowski, D.P., (2007). When agendas collide: human welfare and biological conservation. Conserv. Biol. 21, 59-68.

Costanza, R., d'Arge, R., de Groot, R.S., Farber, S., Grasso, M., Hannon, B., Limburg, K., Naeem, S., O’Neill, R.V., Paruelo, J., Raskin, R.G., Sutton, P., van den Belt, M., (1997). The value of the world's ecosystem services and natural capital. Nature 387, 253-260.

Daily, G. (ed.) (1997). Nature's Services: Societal Dependence on Natural Ecosystems. Island, Washington DC.

De Groot, R. S., Wilson, M. A. and Boumans, R. M. J. (2002). A typology for the classification, description and valuation of ecosystem functions, goods and services. Ecological Economics , 41 , 393 -408.

Ehrlich, P.R., Ehrlich, A.H., (1981). Extinction: the causes and consequences of the disappearance of species. Random House, New York.

Fisher, B., Turner, R \& Morling, P. (2009). Defining and classifying ecosystem services for decision making. Ecological Economics. 68. 643-653. 10.1016/j.ecolecon.2008.09.014

Fraser, E.D., (2004). Land tenure and agricultural management: soil conservation on rented and owned fields in southwest British Columbia. Agric. Hum. Values211, 73-79.

Freeman, A.M.III (2003). The measurement of environmental and resource values: theory and methods, 2nd edn. Resources for the Future, Washington

Ghazoul, J., (2007a). Challenges to the uptake of the ecosystem service rationale for conservation. Conserv. Biol. 21, 1651-1652.

Ghazoul, J., (2007b). Recognising the complexities of ecosystem management and the ecosystem service concept. Glia 16, 215-221.

Hanley, N., Barbier, E.B. (2009). Pricing nature: cost-benefit analysis and environmental 
policy-making. Edward Elgar, London

Heal, G.M., Barbier, E.B., Boyle, K.J., Covich, A.P., Gloss, S.P., Hershner, CH, Hoehn, J.P., Pringle, C.M., Polasky, S., Segerson, K., Shrader-Frechette, K. (2005). Valuing ecosystem services: toward better environmental decision making. The National Academies Press, Washington

Kanninen, B. (ed) (2006). Valuing environmental amenities using stated choice studies: a common sense approach to theory and practice, the economics of non-market goods and services, vol 8. Springer, Dordrecht

Millennium Ecosystem Assessment, (2005). Ecosystems and Human Well-being: Synthesis.

Nachtergaele, F., Biancalani, R., Petri, M., (2011). Land Degradation: SOLAWBackground Thematic Report 3. Food and Agriculture Organization of theUnited Nations, Rome.

Nkonya, E., Gerber, N., von Braun, J., De Pinto, A., (2011). Economics of LandDegradation, 68. IFPRI Issue Brief, Washington, DC.

Pagiola, S., Ritter, K.V., Bishop, J.T. (2004). How much is an ecosystem worth? Assessing the economic value of conservation. The World Bank, Washington

Sklenicka, P. (2016). Classification of farmland ownership fragmentation as a cause of land degradation: A review on typology, consequences, and remedies, Land Use Policy, Volume 57, 2016, Pages 694-701, ISSN 0264-8377, https://doi.org/10.1016/j.landusepol. 2016.06.032.

Ridder, B., 2008. Questioning the ecosystem services argument for biodiversity conservation.

Sachs, J.D., Reid, W.V., (2006). Environment - investments toward sustainable development. Science 312 (5776), 1002.

Sarukhán, J., Whyte, A., Hassan, R., Scholes, R., Ash, N., Carpenter, S.T., Leemans, R., (2005). Millenium Ecosystem Assessment: Ecosystems and Human Well-Being. Island Press, Washington, D.C.

Study of Critical Environmental Problems (SCEP), (1970). Man's Impact on the Global Environment. MIT Press, Cambridge. 319pp.

Wallace, K.J., (2007). Classification of ecosystem services: problems and solutions. Biol. Conserv. 139, 235-246. 